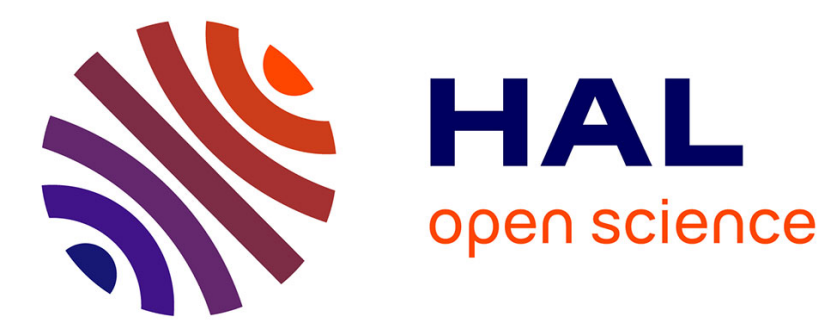

\title{
What's new in cardiogenic shock?
}

Marc Pineton de Chambrun, Dirk W. Donker, Alain Combes

\section{To cite this version:}

Marc Pineton de Chambrun, Dirk W. Donker, Alain Combes. What's new in cardiogenic shock?. Current Opinion in Critical Care, 2020, Publish Ahead of Print (4), pp.424-431. 10.1097/MCC.0000000000000747 . hal-02946517

\section{HAL Id: hal-02946517 https://hal.sorbonne-universite.fr/hal-02946517}

Submitted on 23 Sep 2020

HAL is a multi-disciplinary open access archive for the deposit and dissemination of scientific research documents, whether they are published or not. The documents may come from teaching and research institutions in France or abroad, or from public or private research centers.
L'archive ouverte pluridisciplinaire HAL, est destinée au dépôt et à la diffusion de documents scientifiques de niveau recherche, publiés ou non, émanant des établissements d'enseignement et de recherche français ou étrangers, des laboratoires publics ou privés. 


\section{What's new in cardiogenic shock?}

3

4

5

6 Service de médecine intensive-réanimation, Institut de Cardiologie, APHP Hôpital Pitié-Salpêtrière, 7

8

9

\section{AUTHORS:}

Marc Pineton de Chambrun ${ }^{1}, \mathrm{MD}, \mathrm{MSc}$; Dirk W. Donker ${ }^{1,2}, \mathrm{MD}, \mathrm{PhD}$; Alain Combes ${ }^{1,3}, \mathrm{MD}, \mathrm{PhD}$

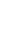
F-75013 PARIS, France

${ }^{2}$ Intensive Care Center, University Medical Center Utrecht, Utrecht University, Utrecht, The Netherlands

${ }^{3}$ Sorbonne Université, INSERM, UMRS_1166-ICAN, Institute of Cardiometabolism and Nutrition, F75013 PARIS, France

\section{Word count: 1134}

Correspondence: Pr Alain Combes, service de médecine intensive-réanimation, Hôpital La Pitié-

Salpêtrière, 47-83 boulevard de I'hôpital, F-75013 Paris, France.

\section{Email: alain.combes@aphp.fr.}

Tel + 33142163818 9

Key-words: cardiogenic shock; acute myocardial infarction; extracorporeal membrane oxygenation; intra-aortic balloon conterpulsation; temporary circulatory support. 
Cardiogenic shock (CS) is defined as primary cardiac dysfunction leading to critical organ

hypoperfusion and hypoxemia. Diagnostic criteria include persistent hypotension and signs of compromised end-organ perfusion such as cold extremities, oliguria, or altered mental status despite correction of underlying hypovolemia[1]. Acute myocardial infarction (AMI) is the most frequent cause of CS, representing up to $70 \%$ of cases and occurring in 5-10\% of patients with AMI. Despite major therapeutic advances, mortality of CS in the setting of AMI remained unacceptably high (40$50 \%)$ in recent years[2]. Since the proportion of patients admitted to intensive care units with CS has increased in recent years, intensivists should benefit from the latest information on the care of this high risk population[3].

\section{A new classification for cardiogenic shock}

Patients with CS represent a heterogeneous population with varying prognosis based on etiology, severity of illness and comorbidities. The Society for Cardiovascular Angiography and Intervention (SCAI) recently proposed a new CS classification featuring 5 stages (A-E) of increasing severity based on clinical, biological and hemodynamic signs of CS (Figure 1) [4]. The purpose of this initiative was to provide a simple tool for bedside evaluation, prognostication and treatment optimization of patients with CS. It also intended to homogenize definitions of CS to appropriately differentiate patient subsets in clinical trials and registries. SCAI CS scores calculated at cardiac intensive care unit admission provided a robust risk prognosis stratification in a Mayo Clinic cohort of 10,000 patients, with the proportion of patients in stages A-E being $46.0 \%, 30.0 \%, 15.7 \%, 7.3 \%$ and $1.0 \%$ and an associated hospital mortality of 3.0\%, 7.1\%, $12.4 \%, 40.4 \%$ and $67 \%(p<0.001)$, respectively[5].

\section{Culprit-lesion-only or multivessel percutaneous coronary intervention (PCI)?}

The CULPRIT-SHOCK trial randomized 706 patients to either culprit-lesion-only PCl or immediate multivessel PCI in CS complicating AMI. The composite primary endpoint (death or renal-replacement therapy within 30-days after randomization) occurred more frequently in the multivessel group ( $55.4 \%$ vs. $45.9 \%, p=0.001)$ and was mostly driven by an increased mortality $(43.3 \%$ vs. $51.5 \% ; p=$ 
1

2

0.03)[6]. After 1 year, the rates of repeat revascularization (32.3\% vs. 9.4\%) and rehospitalisation for heart failure (5.2\% vs. $1.2 \%$ ) were however higher in the culprit-lesion-only group[7]. The latest European Society of Cardiology (ESC) guidelines now recommend against immediate routine multivessel PCl in this setting, while later staged revascularization of other lesions may be performed[8].

(1)

\section{Norepinephrine or epinephrine?}

In current practice, norepinephrine and epinephrine remain the most commonly used vasopressors in CS. A prospective multicenter study that compared the efficacy and safety of epinephrine and norepinephrine in CS complicating AMI was terminated early as the incidence of refractory CS (main safety endpoint) occurred more frequently with epinephrine ( $37 \%$ vs. $7 \%, p=0.008)$. The primary efficacy outcome (cardiac index evolution from baseline to $72 \mathrm{~h}$ ) was however not different between groups ( $p=0.4)[9]$. In a meta-analysis including 16 studies and 2583 patients with CS, epinephrine use was associate with an increased risk of adjusted short-term mortality compared to other drugs (OR $[95 \% \mathrm{Cl}]=4.4[3.4-6.4])$. This result was confirmed in a subset of 338 propensity-matched patients $(\mathrm{OR}[95 \% \mathrm{Cl}]=4.3[3.0-6.0])[10]$. Altogether, these data suggest that norepinephrine but not epinephrine should be considered as the first line vasopressor in patients with CS[1].

\section{Non-pharmalogical interventions}

After promising experimental results, a randomized controlled study that evaluated mild hypothermia $\left(33^{\circ} \mathrm{C}\right)$ in $40 \mathrm{AMI}$ patients with CS failed to demonstrate an improvement in the cardiac power index after $24 \mathrm{~h}$. Mortality at day 30 post-randomization was also not different between groups $(60 \%$ vs. $50 \%, p=0.55)[11]$.

A standardized "shock team" based protocol that included timely diagnosis, mandatory invasive hemodynamic monitoring, and early and appropriate use of circulatory support devices for the management of CS was associated with a significant increase in 30-day survival from 47\% in 2016 (before), to $57.9 \%$ (2017) and 76.6\% (2018) ( $p<0.01)$. A simple 3-category risk score including 
1

2 3

demographic, laboratory, and hemodynamic data was derived from this cohort and may help to guide clinical decision-making in this setting[12].

\section{Temporary circulatory support (TCS)}

The IABP-SHOCK II trial which randomized 600 AMI patients with CS failed to demonstrate any benefit of intra-aortic balloon conterpulsation (IABP) in terms of 30-day, 1-year and 6-years mortality or in any other secondary outcomes[13]. These results led to a class IIIB recommendation against its routine use in the latest ESC guidelines[8].

Other percutaneous short-term TCS device include the Impella ${ }^{\circledR}$ (ABIOMED Inc., Danvers, MA, USA), the TandemHeart ${ }^{\circledR}$ (LivaNova, London, UK) and venoarterial extracorporeal membrane oxygenation (VA-ECMO) which provides both circulatory support and gas exchange. However, guidelines from the ESC (Class Ilb, Level of Evidence C) recommended that TCS implantation should only be considered in selected CS patients[8].

Indeed, a meta-analysis including 4 trials randomizing 148 patients to either TandemHeart ${ }^{\mathrm{TM}}$ or Impella ${ }^{\circledR}(n=77)$ vs. IABP ( $\left.n=71\right)$ showed no difference in 30-day mortality[14]. More recently, two retrospective cohort studies failed to demonstrate a benefit with the Impella ${ }^{\circledR}$. In a study of 237 AMI patients who received the Impella ${ }^{\circledR}$ propensity-matched with 237 patients from the IABP-SHOCK II trial, there was no significant difference in 30 -day all-cause mortality (49\% vs $46 \%, \mathrm{P}=0.64)$ [15]. In a large-scale registry study including 48,306 patients of whom $50 \%$ had CS, undergoing PCI with TCS support at 432 hospitals in the USA, the use of Impella ${ }^{\circledR}$ was even associated with increased mortality (adjusted OR $[95 \% \mathrm{Cl}]=1.17[1.10-1.24] \mathrm{p}<0.001)[16]$. The rates of serious adverse events, including bleeding, infections and stroke, were more frequent in patients supported by the Impella ${ }^{\circledR}$ $[15,16]$. A larger randomized trial comparing the Impella $C P^{\circledR}$ against conventional treatment in 360 AMI CS patients is ongoing (NCT01633502).

While VA-ECMO is currently one of the most commonly applied TCS modalities in CS, high-grade scientific evidence supporting its use is urgently awaited[17] (Supplemental Table 1). A position paper by an international group of ECMO experts advocated for a multidisciplinary team of experts 
1 to guide institutional use of ECMO and the specific care of the patients receiving it. Well-defined

2 patient selection and careful attention to complications were identified as key factors in optimizing

3 outcomes[18]. Percutaneous ECMO cannulation should also be preferred over surgical insertion since

4 a retrospective cohort of 266 propensity-score matched patients showed fewer local infections,

5 similar rates of ischemic or sensory-motor complications and improved 30-day survival with the less

6 invasive approach (63.8\% vs. $56.3 \%, p=0.034)$ [19]. The role of VA-ECMO in AMI patients with CS may

7 be clarified by three large, adequately powered randomized controlled trials (NCT03813134,

8 NCT03637205, NCT04184635) which are currently underway.

9

The new classification of CS may allow improved recognition and care of CS patients. While the initial strategy of revascularization has been clarified in patients with AMI and multivessel disease, TCS devices have yet failed to demonstrate improved survival. More randomized clinical trials are pressingly needed to establish optimal medical, pharmacological and TCS strategies in this setting. Optimized ICU care of these CS patients who frequently develop multiple organ failure may also improve their outcomes. 
2 Figure 1 title: The Society for Cardiovascular Angiography and Intervention (SCAI) cardiogenic shock

3 (CS) classification

4 Figure 1 legend: Abbreviations: SCAl, Society for Cardiovascular Angiography and Intervention; CPR,

5 cardiopulmonary resuscitation; ECMO, extracorporeal membrane oxygenation; TCS, temporary

6 circulatory support; CS, cardiogenic shock; SBP, systolic blood pressure; PEA, pulseless electrical

7 activity; VT, ventricular tachycardia; VF, ventricular fibrillation; NIV, non-invasive ventilation; MV,

8 mechanical ventilation; GFR, glomerular filtration rate; LFTs, liver function tests; BNP, brain

9 natriuretic peptide; MAP, mean arterial pressure; BP, blood pressure; PCWP, pulmonary capillary wedge pressure; RAP, right arterial pressure; PAPi, pulmonary artery pulsatility index; JVP, jugular venous pressure; PA sat, pulmonary artery saturation; CVP, central venous pressure.

${ }^{1}$ Adapted from [3] 


\section{REFERENCES}

1. Mebazaa A, Combes A, van Diepen S, et al (2018) Management of cardiogenic shock complicating myocardial infarction. Intensive Care Med 44:760-773. https://doi.org/10.1007/s00134-018-5214-9

2. Thiele H, Ohman EM, de Waha-Thiele S, et al (2019) Management of cardiogenic shock complicating myocardial infarction: an update 2019. European Heart Journal 40:2671-2683. https://doi.org/10.1093/eurheartj/ehz363

3. Puymirat E, Fagon JY, Aegerter $\mathrm{P}$, et al (2017) Cardiogenic shock in intensive care units: evolution of prevalence, patient profile, management and outcomes, 1997-2012. Eur J Heart Fail 19:192200. https://doi.org/10.1002/ejhf.646

4. Baran DA, Grines CL, Bailey S, et al (2019) SCAI clinical expert consensus statement on the classification of cardiogenic shock: This document was endorsed by the American College of Cardiology (ACC), the American Heart Association (AHA), the Society of Critical Care Medicine (SCCM), and the Society of Thoracic Surgeons (STS) in April 2019. Catheter Cardiovasc Interv 94:29-37. https://doi.org/10.1002/ccd.28329

5. Jentzer JC, van Diepen S, Barsness GW, et al (2019) Cardiogenic Shock Classification to Predict Mortality in the Cardiac Intensive Care Unit. J Am Coll Cardiol 74:2117-2128. https://doi.org/10.1016/j.jacc.2019.07.077

6. Thiele H, Akin I, Sandri M, et al (2017) PCI Strategies in Patients with Acute Myocardial Infarction and Cardiogenic Shock. N Engl J Med 377:2419-2432. https://doi.org/10.1056/NEJMoa1710261

7. Thiele H, Akin I, Sandri M, et al (2018) One-Year Outcomes after PCI Strategies in Cardiogenic Shock. N Engl J Med 379:1699-1710. https://doi.org/10.1056/NEJMoa1808788

8. Neumann F-J, Sousa-Uva M, Ahlsson A, et al (2019) 2018 ESC/EACTS Guidelines on myocardial revascularization. Eur Heart J 40:87-165. https://doi.org/10.1093/eurheartj/ehy394

9. Levy B, Clere-Jehl R, Legras A, et al (2018) Epinephrine Versus Norepinephrine for Cardiogenic Shock After Acute Myocardial Infarction. J Am Coll Cardiol 72:173-182. https://doi.org/10.1016/j.jacc.2018.04.051 
10. Léopold V, Gayat E, Pirracchio R, et al (2018) Epinephrine and short-term survival in cardiogenic shock: an individual data meta-analysis of 2583 patients. Intensive Care Med 44:847-856. https://doi.org/10.1007/s00134-018-5222-9

11. Fuernau G, Beck J, Desch S, et al (2019) Mild Hypothermia in Cardiogenic Shock Complicating Myocardial Infarction. Circulation 139:448-457.

https://doi.org/10.1161/CIRCULATIONAHA.117.032722

12. Tehrani BN, Truesdell AG, Sherwood MW, et al (2019) Standardized Team-Based Care for Cardiogenic Shock. J Am Coll Cardiol 73:1659-1669. https://doi.org/10.1016/j.jacc.2018.12.084

13. Thiele H, Zeymer U, Thelemann N, et al (2018) Intraaortic Balloon Pump in Cardiogenic Shock Complicating Acute Myocardial Infarction: Long-Term 6-Year Outcome of the Randomized IABPSHOCK II Trial. Circulation. https://doi.org/10.1161/CIRCULATIONAHA.118.038201

14. Thiele $H$, Jobs A, Ouweneel DM, et al (2017) Percutaneous short-term active mechanical support devices in cardiogenic shock: a systematic review and collaborative meta-analysis of randomized trials. Eur Heart J 38:3523-3531. https://doi.org/10.1093/eurheartj/ehx363

15. Schrage B, Ibrahim K, Loehn T, et al (2019) Impella Support for Acute Myocardial Infarction Complicated by Cardiogenic Shock. Circulation 139:1249-1258. https://doi.org/10.1161/CIRCULATIONAHA.118.036614

16. Amin AP, Spertus JA, Curtis JP, et al (2019) The Evolving Landscape of Impella ${ }^{\circledR}$ Use in the United States Among Patients Undergoing Percutaneous Coronary Intervention with Mechanical Circulatory Support. Circulation. https://doi.org/10.1161/CIRCULATIONAHA.119.044007

17. Combes A, Brodie D, Chen Y-S, et al (2017) The ICM research agenda on extracorporeal life support. Intensive Care Med 43:1306-1318. https://doi.org/10.1007/s00134-017-4803-3

18. Abrams D, Garan AR, Abdelbary A, et al (2018) Position paper for the organization of ECMO programs for cardiac failure in adults. Intensive Care Med 44:717-729. https://doi.org/10.1007/s00134-018-5064-5 
1 19. Danial P, Hajage D, Nguyen LS, et al (2018) Percutaneous versus surgical femoro-femoral veno-

2 arterial ECMO: a propensity score matched study. Intensive Care Med 44:2153-2161.

3 https://doi.org/10.1007/s00134-018-5442-z

4 